Tropical Journal of Pharmaceutical Research February 2019; 18 (2): 233-241

ISSN: $1596-5996$ (print); 1596-9827 (electronic)

(C) Pharmacotherapy Group, Faculty of Pharmacy, University of Benin, Benin City, 300001 Nigeria.

\title{
Identification of a novel regulatory mechanism involved in inhibition of transcription of suvivin mRNA in breast cancer cells via p21cip-mediated regulation
}

\author{
Hongjie $\mathrm{Xu}^{1 \star}$, Dajun $\mathrm{Wei}^{2}$, Xiaodong $\mathrm{Gai}^{3}$, Ying Jiang ${ }^{4}$ \\ ${ }^{1}$ Department of Oncology, ${ }^{2}$ Department of Cardiology, Affiliated Hospital of Beihua University, ${ }^{3}$ School of Medical Science, \\ Beihua University, Jilin 132011, ${ }^{4}$ Health Service Centers of Wenmiao Community, Changyi District, Jilin 132011, Jilin Province, \\ China
}

*For correspondence: Email: xuhongjie0205@sina.com

\begin{abstract}
Purpose: To evaluate the effect of $p 21^{\text {cip1 }}$ on survivin transcription levels in breast carcinoma, and to investigate the potential mechanisms.

Methods: Epirubicin, a p21 ${ }^{\text {cip } 1}$ activator, was used to treat MCF7 cells. Under the action of normal biological functions of p53, pEGFP-C2-p21 was transfected into MCF7 cells by lipofectamine and positive clones were screened out with G418. The expression levels of p21 $1^{\text {cip }}$, p53 and survivin mRNA were quantitated by real-time fluorescent polymerase chain reaction (RQ-PCR). MTT assay was utilized to measure cellular viability and proliferation after transfection. Flow cytometry was employed to determine the cell cycle. Hoechst 33342 staining was carried out to assess cell apoptosis. Lastly, several transcription factor sites located at the promoter region of survivin gene, such as, sp1 site, E2F site and p300/CBP, were measured by p21 overexpression using RT-PCR.

Results: Following epirubicin treatment, within $24 \mathrm{~h}$, the expression levels of endogenous $p 27^{t^{i p t}}$ and p53 were up-regulated, whereas that of survivin was down-regulated. After transfection treatment, p21 inhibited the proliferation of MCF7 cells on days 3 and 4, and MCF7 cells overexpressed p21 mRNA, whereas the level of survivin mRNA in MCF7-p21 groups was markedly down-regulated relative to control group, but overexpression of p21 was not sufficient to cause changes in p53 gene expression. The overexpressed p21 resulted in G1/GO phase arrest based on cell cycle analysis, but apoptosis was not induced. In addition, co-transcription factors E2F-1, sp1 and p300/CBP mRNA levels decreased significantly compared with normal p21 expression groups.

Conclusion: P21 ${ }^{\text {cip }} 1$ may down-regulate the expression of survivin gene partially by inhibiting the expression level of HAT.
\end{abstract}

Keywords: Cyclin-dependent kinase inhibitor 1, Phosphoprotein p53, Survivin, Breast carcinoma, G1/G0 phase arrest, Epirubicin, Lipofectamine

This is an Open Access article that uses a funding model which does not charge readers or their institutions for access and distributed under the terms of the Creative Commons Attribution License (http://creativecommons.org/licenses/by/4.0) and the Budapest Open Access Initiative (http://www.budapestopenaccessinitiative.org/read), which permit unrestricted use, distribution, and reproduction in any medium, provided the original work is properly credited.

Tropical Journal of Pharmaceutical Research is indexed by Science Citation Index (SciSearch), Scopus, International Pharmaceutical Abstract, Chemical Abstracts, Embase, Index Copernicus, EBSCO, African Index Medicus, JournalSeek, Journal Citation Reports/Science Edition, Directory of Open Access Journals (DOAJ), African Journal Online, Bioline International, Open-J-Gate and Pharmacy Abstracts 


\section{INTRODUCTION}

$\mathrm{p} 21^{\mathrm{cip} 1}$ is the first cyclin-dependent kinase inhibitor (CKI) to be identified, and induction of p21 $1^{\mathrm{cip} 1}$ might cause cell cycle arrest. The p21 $1^{\mathrm{cip} 1}$ is poised to play an important role in preventing tumor development. Previous findings have demonstrated that p21-null mice was more prone to spontaneous and induced tumorigenesis, and in vivo the ectopic expression of p2 $1^{\mathrm{cip} 1}$ protected against tumor progression in mice [1]. On the other hand, reduced levels of $\mathrm{p} 21^{\mathrm{cip} 1}$ transcript have been found in some malignant cells with absence of functional p53, which suggested that low levels of p21 might constitute an advantage in tumor growth [2]. Furthermore, p21 selectively inhibited genes involved in cell-cycle progression, cell division and DNA repair. Some p21-inhibited genes contained E2F or SP1 sites in their promoters, suggesting a highly selective nature of $\mathrm{p} 21^{\mathrm{cip} 1}$-involved inhibition partly mediated through transcriptional factors [3].

Survivin, an anti-apoptotic protein highly expressed in cancer, regulates multiple cellular networks associated with cancer cell viability and prognosis. However, growing reports have suggested that survivin expression is strongly correlated with the proliferation index but not significantly associated with the apoptosis index in carcinoma development [4]. In addition, survivin is expressed during the G2/M phase and in a cell-cycle dependent way. Moreover, survivin expression has been shown to be regulated largely at the transcriptional level. A variety of transcription factors induced by different signaling pathways can activate survivin transcription ${ }^{[5]}$. Therefore, down-regulating the expression level is an important therapeutic option for breast cancer. In this research, the transcriptional regulation of survivin was analyzed to establish survivin as a target gene for new therapeutic approaches and a novel regulatory mechanism within the survivin promoter was investigated.

In this present study, breast carcinoma cell line MCF7 was treated with epirubicin, which simultaneously caused the accumulation of endogenous $\mathrm{p} 53$ and $\mathrm{p} 21^{\mathrm{cip} 1}$ gene and downregulate the expression of survivin mRNA within 24 hours after treatment. Based on the effects of survivin on cell cycle, it is hypothesized that it may serve as a target candidate for p21 regulation at the transcriptional level.

Therefore, the eukaryotic vector pEGFP-C2p2 $1^{\text {cip } 1}$ was stably transfected into MCF7 cells, which overexpressed p21 gene. The changes in the expression levels of p21, p53 and survivin
mRNA were determined with RT-PCR to study whether p21 $1^{\mathrm{cip} 1}$ can inhibit survivin mRNA expression. Consequently, in this particular system, p21 $1^{\text {cip1 }}$ overexpression could downregulate the expression level of survivin mRNA in a p21-specific manner, but did not completely act at the downstream events of p53 signaling pathway. The effects of p21 $1^{\mathrm{cip} 1}$ were confirmed by cell cycle phase detection and transcriptional cofactors of p300/CBP, E2F or sp1 activity analysis at the transcriptional level, which are the key regulation factors of survivin expression. These results characterize a novel survivin signaling pathway in cell cycle development in MCF7 cells.

\section{EXPERIMENTAL}

\section{Materials and reagents}

Dulbecco's Modified Eagle Medium (DMEM), fetal bovine serum (FBS) and G418 were obtained from Gibco BRL. Epirubicin and propidium iodide $(\mathrm{PI})$ were obtained from Sigma Chemical Company. Lipofectamine 2000, Trizol reagent and Hoechst 33342 were purchased from Invitrogen Company. ReverTra Ace-a-first strand $c D N A$ synthesis kit was purchased from TOYOBO Co. (Osaka, Japan). PGEM-T-easy vector system was purchased from Promega Company. Real-time fluorescence quantitative PCR detection kit for GAPDH gene was purchased from ShenYou Biotechnology Co. (Shanghai, China). SyberGreen I and LightCycler analyzer were supplied by Roche Diagnostics.

\section{Epirubicin treatment}

MCF7 cell line, a human breast cancer cell line was maintained in DMEM with $10 \%$ FBS, 100 $\mathrm{U} / \mathrm{mL}$ penicillin and $100 \mu \mathrm{g} / \mathrm{mL}$ streptomycin. Cultures were performed at $37^{\circ} \mathrm{C}$ in a $5 \% \mathrm{CO}_{2}$ atmosphere and passaged every 3 days. For drug treatment, exponentially growing cells were treated with $0.2 \mu \mathrm{g} / \mathrm{mL}$ (final concentration) epirubicin then harvested for total RNA extraction at the indicated time $(0 \mathrm{~h}, 8 \mathrm{~h}, 12 \mathrm{~h}, 24 \mathrm{~h}, 48 \mathrm{~h})$.

\section{Extraction and digestion of transfected plasmids}

Bacterial fluid containing pcDNA3 or pcDNA3p21 plasmid was taken and plasmids were extracted and purified according to the manufacturers' instructions. After dilution, the concentration and purity of the plasmids were measured. pcDNA3-p21 was used as the template, oligonucleotide primers were designed to amplify p21 ${ }^{\text {cip1 }}$ open reading frame (ORF) as follows: upper primer 5'-CCG GAA TTC ATG 
TCA GAA CCG GCT GGG-3'; lower primer 5'CCG GGA TCC GGG CTT CCT CTT GGA GAA GAT-3'. Using the polymerase chain reaction (PCR), EcoR I and a BamH I enzymes were added to the 5' and 3' terminus of the cDNA coding for $\mathrm{p} 21^{\mathrm{cip} 1}$, respectively. The $495 \mathrm{bp}$ fragments of $\mathrm{p} 21^{\mathrm{cip}}{ }^{1} \mathrm{cDNA}$ were cloned into the expressing vector pEGFP-C2, and positive clones were screened from the transformed $\mathrm{DH} 5 \alpha$. The constructed plasmid (designated as pEGFP-C2- p21 $1^{\mathrm{cip} 1}$ ) was identified by restriction enzyme analysis and verified by DNA sequencing.

\section{Gene transfection and subclone cell line selection}

MCF7 cells were seeded onto 6-well plates. When the cell density reached $85 \%$, pEGFP-C2p2 $1^{\text {cip } 1}$ or pEGFP-C2 plasmids were introduced into the MCF7 cells according to the kit instructions of Lipofectamine2000. After transfection for $24 \mathrm{~h}$, the liquid was replaced and cells were cultured for another $48 \mathrm{~h}$. Afterwards, selective medium (G418 at $800 \mu \mathrm{g} / \mathrm{mL}$ ) was added for cell screening for about 2 weeks. Once most of the non-transfected cells were dead, the concentration of G418 was decreased to $400 \mu \mathrm{g} / \mathrm{mL}$ and maintained for another 2 weeks. After cellular clones' formation, subclones were chosen at random and amplified. The subclone cells expressing GFP-p21 and GFP-neo genes were named as MCF7-p21 and MCF7-C2.

After completion of the 4 weeks selection period, individual clones were isolated and subcultured in selection medium. Subcultured cell was harvested and cellular total RNA was extracted with Trizol reagent kit. Isolated RNA was stored in diethylpyrocarbonate (DEPC)-treated water at $70{ }^{\circ} \mathrm{C}$. RNA concentration was determined by absorbance readings at $260 \mathrm{~nm}$ utilizing an ultraviolet spectrometry. Reverse transcription of RNA was then performed with oligo $(\mathrm{dT})_{20}$ priming and ReverTra Ace-a-first strand cDNA synthesis kit.

\section{Cell viability assays}

MCF7 cells at logarithmic growth stage was taken, made into cell suspension of $2 \times 10^{4} / \mathrm{mL}$ and seeded onto 96-well plates, with each well containing $200 \mu \mathrm{L}$ of cell suspension and each group having 6 wells. From the first to the fifth day, the cells were stained to detect the cell growth of MCF7 and examine the inhibitory effect of epirubicin alone or adriamycin plus p21 transfection on the cell proliferation of MCF7 cells. Before the termination of the test, $20 \mu \mathrm{L}$ MTT was added to each well and $4 \mathrm{~h}$ later the media were discarded. Then $150 \mu \mathrm{L}$ DMSO was added to dissolving formazan crystals, and the samples were read on a plate reader at a wavelength of $570 \mathrm{~nm}$ to determine their absorbance $\left(A_{570}\right)$. All the experiments were repeated three times.

Since the initial cell concentration of samples of the transfection group might differ, in this study, the $A_{570}$ value measured at each time point was divided by the corresponding initial $A_{570}$ value and the ratios were used for plotting the curve of cell growth trend over time (day) after the transfection. The cell inhibition rate (IR) was calculated by the following formula: $I R=(1-$ average $A$ value of the experimental group/A value of the control group) $\times 100 \%$. The inhibition curve over time (day) was prepared.

\section{Real-time quantitative PCR}

The primers of $\mathrm{p} 21^{\mathrm{cip} 1}, \mathrm{p} 53$ and survivin were designed and synthesized by Takara life Technique Company, then purified by PAGE. Real-time quantitative PCR, utilizing $2 \mu \mathrm{l}$ cDNA, was performed using the gene-specific primer, the sequence of primers were listed in Table 1, and the transcription level of GAPDH gene was confirmed as a housekeeping target.

Real-time PCR was performed on Lightcycler real-time PCR system. The reaction mixture contained $1 \mu \mathrm{L}$ upper primer and lower primer (10 pmol/ $\mu \mathrm{L}), 0.4 \mu \mathrm{L} \mathrm{dNTP}$ mixture $(10 \mathrm{mmol} / \mathrm{L})$, $2 \mu \mathrm{L} 10 \times$ buffer, $3.2 \mu \mathrm{L} \mathrm{MgCl}_{2}(25 \mathrm{mmol} / \mathrm{L}), 1 \mu \mathrm{L}$ SyberGreen I (20x), $2 \mu \mathrm{L}$ cDNA template, $1 \mu \mathrm{L}$ Taq polymerase $(1 \mathrm{U})$ and $8.4 \mu \mathrm{L} \mathrm{H}_{2} \mathrm{O}$. The amplification conditions were as follows: predenatured at $94{ }^{\circ} \mathrm{C}$ for $2 \mathrm{~min}$, followed by 40 cycles (denatured at $94{ }^{\circ} \mathrm{C}$ for $5 \mathrm{~s}$, annealed at different temperatures as below for $15 \mathrm{~s}$, extended at $72{ }^{\circ} \mathrm{C}$ for $15 \mathrm{~s}$ and measured fluorescence intensity at $85{ }^{\circ} \mathrm{C}$ for $3 \mathrm{~s}$ ), then cooled at $40{ }^{\circ} \mathrm{C}$ for $30 \mathrm{~s}$. Additionally, melting curve analysis was performed to verify the specificity of all PCR products.

\section{Standard curves analysis}

In this study, plasmid pEGFP-C2-p21 ${ }^{\text {cip } 1}$, pGEMT-easy-p53, pGEM-T-easy-survivin were used as standards respectively. pGEM-T vector consisted of p53 or survivin gene PCR product prepared by T-A clone as described in the pGEM-T-easy manual (Promega). The standard concentration was quantitated with ultraviolet spectrometry.

The amount of the selected genes mRNA was determined by comparison with the generated standard curve and normalized with 
housekeeping gene GAPDH of the same sample, respectively. For each sample, the corrected gene mRNA concentration was described as follows, the level of corrected gene mRNA $=10^{4}$ $\times[\mathrm{C}]_{\text {analyzed }}$ gene $/[\mathrm{C}]_{\mathrm{GAPDH}}$. This normalization against the housekeeping gene was feasible if both PCR presented the same efficiency. This latter was assessd by the slope of the standard curve for each PCR run, as in Eq 1.

Efficiency $=\left\{10^{(1 / \text { slope })}\right\}$

\section{Flow cytometry}

Cell $\left(1 \times 10^{6} / \mathrm{mL}\right)$ was harvested by trypsin treatment, washed with cold PBS, and fixed in 70 $\%$ ethanol at $-20{ }^{\circ} \mathrm{C}$ overnight. The next day the cell was also washed twice in cold PBS, then stained with $\mathrm{PI}$ solution $(50 \mathrm{mg} / \mathrm{mL} \mathrm{PI}, 100$ $\mathrm{mg} / \mathrm{mL}$ RNase, and $0.1 \%$ Triton X-100 in PBS) for $30 \mathrm{~min}$ at $4{ }^{\circ} \mathrm{C}$. The stained cell was analyzed for DNA histograms and cell cycle phase distribution by flow cytometry (FACSCalibur, BD Bioscience). G0/G1, S and G2/M phase cell populations were measured according to the program CellQuest.

\section{Apoptosis assessment}

Hoechst 33342 is a cell-permeable DNA stain that is excited by ultraviolet light and emits blue fluorescence at 460 to $490 \mathrm{~nm}$. MCF7 cells $\left(2 \times 10^{5}\right.$ cells/well in a six-well plate) were treated with epirubicin for $0,8,16$ and $24 \mathrm{~h}$. After trypsinization, cells were washed with $1 \mathrm{X}$ PBS and stained with $3 \mu \mathrm{g} / \mathrm{mL}$ of Hoechst 33342 for 15 min. Stained cells were examined using fluorescence microscope (Olympus, Japan) with an ultraviolet filter.

Table 1: Primer sequences for RT-PCR

\section{Transcription factors analysis}

cDNA of above transfected groups (MCF7-p21, MCF7-C2 and MCF7 ) were used as templates. Primers for E2F-1, SP1 and p300/CBP were designed using Primer 6.0 software and tested to ensure amplification of single discrete bands with no primer-dimers; the sequence of primers are listed in Table 1. For control, human housekeeping gene GAPDH was synthesized from the same amount of RNA from respective sources.

All PCR products were analyzed by electrophoresis on $2 \%$ agarose gels containing $0.5 \mathrm{mg} / \mathrm{L}$ ethidium bromide. The amplified products were visualized and photographed under ultraviolet light, scanned and analyzed by UVP bioimage system.

\section{Statistical analysis}

The software SPSS for Windows version 17.0 was used for statistical analysis and each experiment was repeated at least three times. The values were expressed as the mean $\pm S$.D. and then statistical analysis of the data was performed using Student-Newman-Keuls - test and Dunnett's T3 - test. $P<0.05$ was considered statistically significant.

\section{RESULTS}

\section{Standard RT-PCR curve}

Real-time PCR standard curve for the p2 $1^{\text {cip1 }}$ gene, p53, survivin and GAPDH is $\mathrm{Ct}_{\mathrm{p} 21}=-$ $3.649 \log [\mathrm{C}]_{\mathrm{p} 21}+44.83$, Ct ${ }_{\mathrm{p} 53}=-3.597$ $\log [\mathrm{C}] \mathrm{P} 53+44.08, \mathrm{Ct}$ surviving $=-$ $3.378 \log [\mathrm{C}]_{\text {survivin }}+42.53$, and $\mathrm{Ct} \mathrm{GAPDH}=-$ $3.86 \log [\mathrm{C}]_{\text {GAPDH }}+46.70$ respectively. The $\mathrm{Ct}$ values were plotted versus the log of the initial concentration of the positive standards, and the

\begin{tabular}{|c|c|c|c|c|}
\hline \multirow{2}{*}{$\begin{array}{l}\text { Primer } \\
\text { GAPDH }\end{array}$} & & Sequence $\left(5^{\prime}-3^{\prime}\right)$ & Length(bp) & Temp $\left({ }^{\circ} \mathrm{C}\right)$ \\
\hline & $\begin{array}{l}\text { Forward } \\
\text { Reverse }\end{array}$ & $\begin{array}{l}\text { 5'-GAA GGT GAA GGT CGG AGT C-3' } \\
\text { 5'-GAA GAT GGT GAT GGG ATT C-3' }\end{array}$ & 226 & 60 \\
\hline p21 & $\begin{array}{l}\text { Forward } \\
\text { Reverse }\end{array}$ & $\begin{array}{l}\text { 5'-CAG GGG ACA GCA GAG GAA GA-3' } \\
\text { 5'-TTA GGG CTT CCT CTT GGA GAA-3' }\end{array}$ & 188 & 58 \\
\hline p53 & $\begin{array}{l}\text { Forward } \\
\text { Reverse }\end{array}$ & $\begin{array}{l}\text { 5'-TCA ACA AGA TGT TTT GCC AAC TG-3' } \\
\text { 5'-ATG TGC TGT GAC TGC TTG TAG ATG-3' }\end{array}$ & 118 & 59 \\
\hline survivin & $\begin{array}{l}\text { Forward } \\
\text { Reverse }\end{array}$ & $\begin{array}{l}\text { 5'-AGA ACT GGC CCT TCT TGG AGG-3' } \\
\text { 5'-CTT TTT ATG TTC CTC TAT GGG GTC-3' }\end{array}$ & 170 & 60 \\
\hline $\mathrm{p} 300 / \mathrm{CBP}$ & $\begin{array}{l}\text { Forward } \\
\text { Reverse }\end{array}$ & $\begin{array}{l}\text { 5'-GGG AGG GTG AAC TCT ACT TTC C-3' } \\
\text { 5'-TCC AGG TAG GAG ACA TGA ACT C-3' }\end{array}$ & 121 & 61 \\
\hline SP1 & $\begin{array}{l}\text { Forward } \\
\text { Reverse }\end{array}$ & $\begin{array}{l}\text { 5'-CTG GTC ATA CTG TGG GAA ACG C-3 } \\
\text { 5'-TGT TGG CAA GAC GGG CAA TG-3' }\end{array}$ & 317 & 55 \\
\hline $\mathrm{E} 2 \mathrm{~F}-1$ & $\begin{array}{l}\text { Forward } \\
\text { Reverse }\end{array}$ & $\begin{array}{l}\text { 5'-TGC CCT GAG GAG ACC GTA G-3' } \\
\text { 5'-GGT GAC ACT ATG GTG GCA GAG-3' }\end{array}$ & 107 & 63 \\
\hline
\end{tabular}


Table 2: p21, p53 and survivin mRNA level in MCF7 cell with epirubicin treatment

\begin{tabular}{lcccccc}
\hline Group & $\begin{array}{c}\text { Level of } \\
\text { p21 mRNA }\end{array}$ & SI & $\begin{array}{c}\text { Level of } \\
\text { p53 mRNA }\end{array}$ & SI & $\begin{array}{c}\text { Level of } \\
\text { survivin mRNA }\end{array}$ & SI \\
\hline Control & $11.1 \pm 1.22$ & & $4.99 \pm 1.09$ & & $394.85 \pm 60.28$ & $t=2.69$ \\
$8 \mathrm{~h}$ & $377.79 \pm 118.52$ & $t=5.36$ & $1747.1 \pm 1018.66$ & $t=2.96$ & $286.51 \pm 34.77$ & $p>0.05$ \\
& & $p<0.05$ & & $p<0.05$ & & $t=7.31$ \\
$12 \mathrm{~h}$ & $1283.15 \pm 150.65$ & $t=11.09$ & $18290.89 \pm 6290.4$ & $t=18.81$ & $112.09 \pm 29.27$ & $p<0.01$ \\
& & $p<0.01$ & & $p<0.01$ & & $t=10.22$ \\
$24 \mathrm{~h}$ & $2054.05 \pm 511.63$ & $t=6.91$ & $6910.86 \pm 1257.45$ & $t=4.21$ & \multirow{2}{*}{$37.03 \pm 6.43$} & $p<0.01$ \\
& & $p<0.01$ & & $p<0.05$ & & \\
$48 \mathrm{~h}$ & $21.35 \pm 5.48$ & $t=2.01$ & $284.75 \pm 70.58$ & $t=6.86$ & $274.83 \pm 113.23$ & $p>0.05$ \\
\hline
\end{tabular}

Note: the measurement unit of mRNA relative level is copies $/ \mathrm{ml}$

correlation coefficient between initial slow but was not significantly different from that concentration and number of cycles was always of MCF7-C2 transfection group $(t=1.61, p>$ $\operatorname{good}\left(R^{2} \geq 0.98\right)$.

P21, p53 and survivin mRNA level after treatment with epirubicin

After MCF7 cells were treated with epirubicin, in comparison with the control group, the mRNA level of p2 $1^{\text {cip } 1}$, p53 and survivin are shown in Table 2. In other words, the level of $\mathrm{p} 21^{\text {cip } 1}$ mRNA gradually increased within $24 \mathrm{~h}$ and increased up to 180.18 -fold at $24 \mathrm{~h}$ over the control group at $\mathrm{Oh}$; on the other hand, survivin mRNA expression was decreased to about 9.37 $\%$ of basal level at $24 \mathrm{~h}$. Furthermore, the p2 $1^{\mathrm{cip} 1}$ mRNA level was almost restored to the baseline level at $48 \mathrm{~h}$ after epirubicin treatment. Moreover, the survivin mRNA level was restored $54.87 \%$ of the baseline level.

\section{p21 mRNA level after transfection}

MCF7 cell was stably transfected with p21 gene, and the transfection efficiency was determined by real time PCR. Table 3 showed that the expression of p21increased significantly after transfection $(F=9.92, \quad p<0.05)$, that is to say, the expression of p21 increased by 2100.11 and 980.89 - fold in MCF7 and MCF7-C2 over that in the MCF7-p21, respectively. However, the levels of p21 mRNA between MCF7 and MCF7C2 did not significantly differ $(p>0.05)$.

\section{Growth curve of MCF7 cells after transfection}

MTT assay showed that cell proliferation in the blank control and MCF7-C2 transfection group did not significantly differ at different time points (all $p>0.05$ ) (Figure 2). To eliminate the possible influence of vectors, the results between the MCF7-p21 and MCF7-C2 groups were statistically compared by match-paired analysis. At 2 days before the culture, the cell growth in MCF7-p21 transfection group gradually became $0.05)$, while on the $3^{\text {rd }}$ and $4^{\text {th }}$ days, statistical significance was observed between the two groups (the $3^{\text {rd }}$ day: $t=4.04, p<0.01$; the $4^{\text {th }}$ day: $t=6.80, p<0.01)$. On the $5^{\text {th }}$ day, the growth of MCF7-p21 transfection group was stable and showed no significant difference as compared with the previous time points $(t=0.79$, $p>0.05)$. The cell growth in the control group was slow and the proliferation rate was low. No significant difference was found between two groups $(t=1.37, p>0.05)$, indicating that $\mathrm{p} 21$ gene could inhibit the growth of MCF7 cells during certain time period.

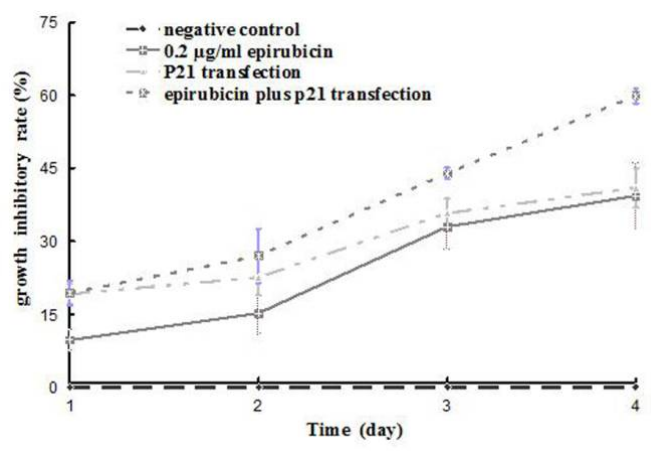

Figure 2: Inhibitory effects of epirubicin or/and p21 gene transfection on proliferation of MCF7 cells

\section{Effect of p21 gene on p53 or survivin mRNA expression}

As shown in Table 2 and Figure 1, the expression intensities of survivin mRNA in MCF7-p21 cells were significantly decreased compared with those in the other two groups $(F=$ 114.19 , both $P<0.01$ ), and was similarly downregulated to 0.54 and $0.59 \%$ relative to the other groups. On the other hand, the combined data indicated that over-expression of p21 was insufficient to cause the changes of p53 gene expression. 
Table 3: p21, p53 and survivin mRNA level in MCF7 cell after transfection

\begin{tabular}{lccc}
\hline Group & p21 mRNA & p53 mRNA & Survivin mRNA \\
\hline MCF7 & $12.41 \pm 3.14$ & $7.03 \pm 2.46$ & $116.71 \pm 62.02$ \\
MCF7-C2 & $26.57 \pm 7.95$ & $8.76 \pm 2.51$ & $109.32 \pm 19.56$ \\
MCF7-p21 & $26062.35 \pm 18861.58^{*}$ & $12.92 \pm 10.09$ & $0.64 \pm 0.14^{*}$ \\
SI & $P=0.013$ & $P=0.29$ & $P=0.001$ \\
\hline
\end{tabular}

Note: ${ }^{*} P<0.05$ as compared with MCF7 group; ${ }^{\#} p<0.05$ as compared with MCF7-C2 group. Measurement unit of $\mathrm{mRNA}$ relative level is copies $/ \mathrm{ml}$
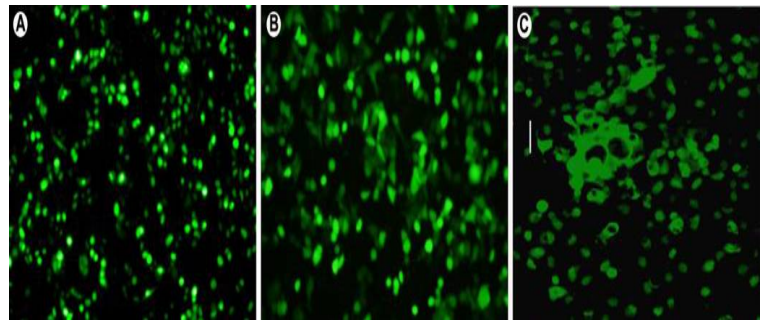

Figure 1: Gene expression in MCF7 cells transfected with pEGFP-P21 $(A, \times 400)$ or pEGFP-C2 plasmid $(B, \times 400)$ and positive colon of MCF7-p21 cells by G418 by fluorescence microscopy analysis $(C, \times 400)$

\section{Cell cycle progression}

As demonstrated in Figure 3, p21 gene could inhibit DNA synthesis and increased the percentage of cell in G0/G1 phase (72.55 \pm 2.88 in MCF7-p21 cell compared with $51.79 \pm 2.02$ and $55.37 \pm 4.77$ in MCF7 and MCF7-C2 cell controls, $F=31.59, p=0.001$ ). This increase was coupled with decreased percentage of $S$ phase cells (17.19 \pm 0.37 in MCF7-p21 cells compared with $32.46 \pm 2.35$ and $29.3 \pm 3.61$ in relative controls, $F=67.18, p=0.000)$; and diminished percentage of $\mathrm{G} 2 / \mathrm{M}$ phase cells $(10.26 \pm 2.6$ in MCF7-p21 relative to $15.76 \pm 0.94$ and $15.33 \pm 1.18$ in the controls, $F=27.02, p=$ $0.001)$.
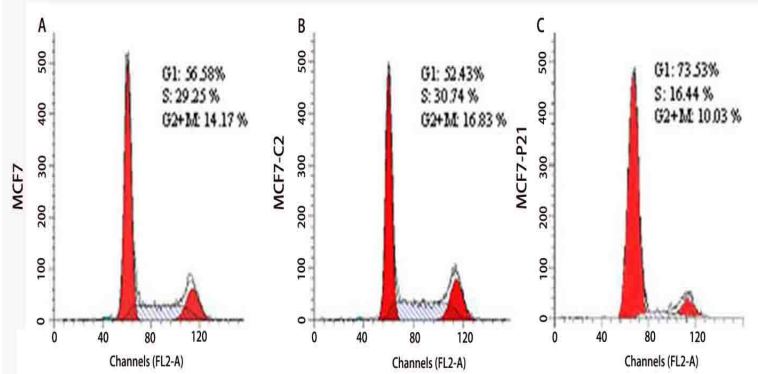

Figure 3: Cell cycle phase patterns of $\operatorname{MCF} 7(A)$, MCF7-C2 (B) and MCF7-P21 (C) after transfection

\section{p21 induced apoptosis analysis in MCF7}

In a pilot assay with Hoechst 33342, a rapid assay based on fluorescence detection of compacted chromatin in apoptotic cells, the condensed chromatin of apoptotic cells stain more brightly than the chromatin of normal cells. The control cells exhibited uniformly dispersed chromatin, normal organelles, and intact cell membranes. As shown in Figure 4C, cells incubated with Hoechst 33342 compounds for 24 h showed of apoptotic cell staining. Conversely, transfecting p21 gene of MCF7 cells did not increase the number of apoptotic nuclei compared to control treatment (Figure 4 to Figure $5)$.
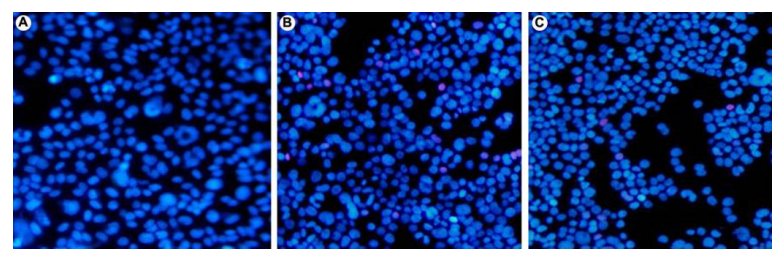

Figure 4: Morphology of the MCF7cells stained with Hoechst33342/PI after transfection. A: cells in control group; B: cells transfected with pEGFP-C2; C: cells transfected with pEGFP-P21

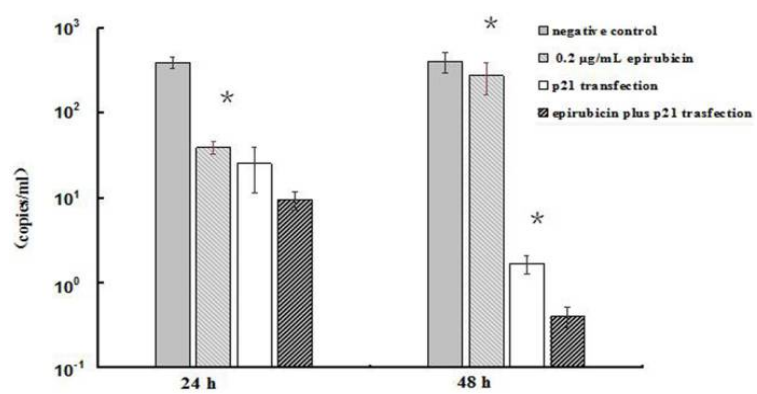

Figure 5: Expression of survivin mRNA in MCF7 cells after different treatments

\section{Effect of transcription factors on the mRNA expression after transfection}

As shown in Figure 6, the E2F-1/GAPDH ratio detected with UVP Bioimage System in MCF7p21 was $0.75 \pm 0.04$, as well as $1.42 \pm 0.09$ and $1.56 \pm 0.06$ in MCF7-C2 and MCF7, respectively, and statistical analysis showed that E2F-1 mRNA down-regulated significantly after transfecting with p21 $(p<0.05)$; and SP1, one of the most important transcription factor for survivin, in MCF7-p21 was $0.98 \pm 0.05$, as well as $1.32 \pm$ 0.11 and $1.43 \pm 0.15$ in MCF7-C2 and MCF7; It showed that p21decreased SP1 mRNA expression. In addition, p300/CBP in MCF7-p21 was $0.18 \pm 0.06$, as well as $0.98 \pm 0.05,0.95$ \pm 0.19 in MCF7-C2 and MCF7 respectively, which 
suggest that $\mathrm{p} 300 / \mathrm{CBP}$ mRNA also decreased significantly after transfecting with p21 $(p<0.05)$.
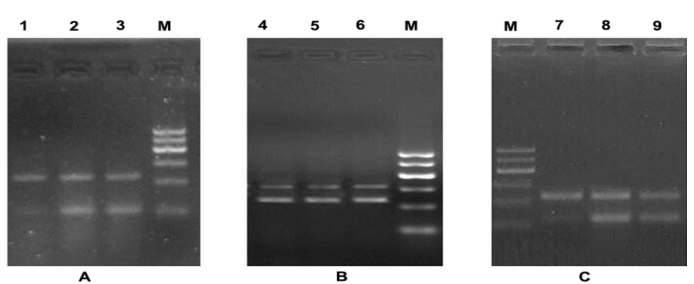

Figure 6: Expression of transcription factors mRNA in MCF7 cell after p21 gene transfection. M: DNA marker I $(100,200,300,400,500,600 \mathrm{bp}$ from lower to upper; 1, 4, 7: MCF7-p21 cell ; 2, 5, 8: MCF7-C2 cell; 3, 6, 9: MCF-7 cell; A: upper line is GAPDH (226bp); lower line is E2F-1(107bp); $\mathrm{B}$ : upper line is $\mathrm{SP} 1(317$ $\mathrm{bp}$ ); lower line is GAPDH (226 bp); C: upper line is GAPDH (226 bp); lower line is p300/CBP (107 bp)

\section{DISCUSSION}

Survivin, a pivotal cancer gene, is increasingly drawing the attention of researchers. It is specifically expressed in some tumors and or fetal tissues and is barely found in normal adult tissues [6]. In the past, research effort was mainly directed at its anti-apoptotic effect. Recently, it is closely related to the cell cycle progression and can promote cell proliferation in breast tumors. Clinically, high level of survivin is associated with lower survival, drug resistance and poor prognosis $[7,8]$, suggesting that survivin might be involved in the malignant changes of breast tumors. Therefore, regulation of survivin at the transcription level captivates more and more attention from oncologists.

As an inhibitor of topo-isomerases I and II, epirubicin can induce DNA damage, activate P53-P21 pathway and down-regulate phosphorylation of RB proteins, thereby causing cell cycle arrest at $G_{1}$ phase. It can also induce cell cycle arrest at $G_{2}$ phase by down-regulating the expression of Cyclin B1, and inhibiting the phosphorylation of $\mathrm{CDC} 2$ and histone $\mathrm{H} 3$, thereby suppressing the growth of tumor cells $[9,10]$.

In this study, human breast carcinoma cell line MCF7 was treated with epirubicin, which is the most efficient chemotherapy agent in the clinical treatment of breast cancer [11], and it inhibited the growth of MCF7 cells to some extent. At 24 and $48 \mathrm{~h}$ after the treatment, the expression of survivin mRNA was lower than that of the untreated group but no significant difference was found between two groups at the two time points. Furthermore, the level of p21 mRNA was increased gradually and reached the highest level at $24 \mathrm{~h}$ after treatment with epirubicin. When the p21 mRNA levels were almost restored to baseline levels at $48 \mathrm{~h}$ after epirubicin treatment, the survivin mRNA levels was restored to approximately $54.87 \%$ of the baseline level, which indicated that p21 inhibited survivin expression at the transcription level directly or indirectly and epirubicin may be simultaneously involved in inhibiting survivin gene expression at transcription level.

Genotoxic agents, such as adriamycin, can specifically inactivate survivin by activating P53 signal pathway, thereby inhibiting its expression. Hoffman et al [12], by analyzing the start codon of survivin, found that inhibition of survivin transcription was achieved by the interaction of down-stream target molecules of wild-type p53. The p21 protein, a cyclin-dependent protein kinase inhibitor, is an important tumor suppressor gene of down-stream target molecules of wildtype p53 and the biological functions of p53 requires the help of $p 21$.

p21 gene is highly conservative and rarely mutates in tumorigenesis. As a down-stream molecule, the broad-spectrum mutation of p53 gene may lead to p21cip1 reduced expression or absence of the expression, thereby inhibiting its functions and loss of p21 functions was highly associated with some pre-cancerous changes, suggesting that p21 might outperform p53 as a tumor suppressor gene [13]. In this research, we investigated whether p21 $1^{\text {ip } 1}$ is involved in inhibiting survivin expression at the transcription level directly or indirectly, using an extrinsic p2 $1^{\text {cip1 }}$ gene was transfected into MCF7 breast cancer cells, containing wild-type p53 and the normal biological functions of p53.

After transfection treatment, MCF7 cells which induced its overexpression and the expression levels of p21 mRNA inMCF7, MCF7-C2 and MCF7-p21 groups were $12.41 \pm 3.14$ copies $/ \mathrm{mL}$, $26.57 \pm 7.95$ copies $/ \mathrm{mL}$, and $26062.35 \pm$ 18861.58 copies $/ \mathrm{mL}$ respectively, whereas the level of survivin mRNA in MCF7, MCF7-C2 and MCF7-p21 groups was $116.71 \pm 62.02,109.32 \pm$ 19.56 and $0.64 \pm 0.14$ respectively. The results indicated that p21 overexpression could inhibit the expression of survivin at transcriptional level. Flow cytometry revealed that the quantity of cells in G0/G1 was remarkably increased accompanied with the decreasing number of $S$ or G2/M cells due to p21 overexpression, but its overexpression did not induce the apoptosis of MCF7 cells observed by Hoechst33342 staining. It suggested that survivin could be characterized by cell cycle dependent expression, which is mainly expressed in G2/M phase. It is speculated 
that p21 might down-regulate the expression of survivin gene through cell cycle arrest in G0/G1 phase to some extent.

Because p21 might negatively regulate the expression of survivin gene at the transcription level through cell cycle arrest in G0/G1 phase, part of transcription factors at the promoter region of survivin gene were inhibited by overexpression of p21. Several transcription factor sites have been found at the promoter region of survivin gene, for example, Sp1, E2F and NF-KB sites [14]. RT-PCR demonstrated that p21 overexpression could down-regulate the expression level of E2F-1, as one of E2F family transcription factors. p21 overexpression could down-regulate the expression level of SP1, as one of the most important transcription factors for survivin [14]. Therefore, p21 might negatively regulate the expression of survivin gene at the transcription level partially by inhibiting the expression levels of E2F-1 and SP $1[15,16]$.

Recent studies have demonstrated that the acetylation state of histones exerts a major influence on transcriptional activity of survivin gene, and decreases histone acetylases activity is frequently involved in transcriptional repression [17]. In this study, p21 overexpression could also inhibiting the activity of histone acetyltransferases (HAT) p300/CBP by suppressing its expression at transcription levels. p300/CBP can transfer an acetyl group to the eamino group of a lysine residue in the $\mathrm{NH}_{2}$ termination of histone $\mathrm{H} 3$, and in this respect lead to the alteration of chromatin structure and affect access of transcription factors to nucleosomal DNA [18].

Additionally, p300/CBP can be recruited to promoter of survivin gene by a large number of DNA-binding proteins and stimulate gene expression either through their inherent HAT activity or through its ability to interact with other coactivators and components of the basal transcriptional machinery [19]. Zhu N et al [20] reported that repression of survivin gene expression could result from suppression of histone acetylation of the promoter in the wildtype p53-dependent manner.

\section{CONCLUSION}

Based on the findings of the present study, it appears conceivable that p2 $1^{\text {cip } 1}$ may negatively regulate the expression of survivin gene partially through inhibiting the expression level of HAT.

\section{DECLARATIONS}

\section{Acknowledgement}

This work was funded by Jilin Provincial Department of Education Funding Project (Grant no. JJKH20180360KJ).

\section{Conflict of Interest}

No conflict of interest associated with this work.

\section{Contribution of Authors}

The authors declare that this work was done by the authors named in this article and all liabilities pertaining to claims relating to the content of this article will be borne by them.

\section{REFERENCES}

1. Martín-Caballero J, Flores JM, García-Palencia $P$, Serrano M. Tumor susceptibility of p21 (Waf1/Cip1)deficient mice. Cancer Res 2001; 61: 6234-6238.

2. Yoshino A, Katayama Y, Ogino A, Watanabe T, Yachi K, Ohta $T$, Komine C, Yokoyama $T$, Fukushima $T$. Promoter hypermethylation profile of cell cycle regulator genes in pituitary adenomas. J Neurooncol. 2007; 83(2): 153-162.

3. Ohta $T$, Watanabe $T$, Katayama $Y$, Yoshino A, Yachi $K$, Ogino A, Komine C, Fukushima T. Aberrant promoter hypermethylation profile of cell cycle regulatory genes in malignant astrocytomas. Oncol Rep. 2006; 16(5): 957963.

4. Nassar A, Sexton D, Cotsonis G, Cohen C. Survivin expression in breast carcinoma: correlation with apoptosis and prognosis. Appl Immunohistochem Mol Morphol. 2008; 16(3): 221-226.

5. Chun JY, Hu Y, Pinder E, Wu J, Li F, Gao AC. Selenium inhibition of survivin expression by preventing Sp1 binding to its promoter. Mol Cancer Ther 2007; 6: 25722580.

6. Altieri DC. Survivin, versatile modulation of cell division and apoptosis in cancer. Oncogene 2003, 22(53): 8581 -8589 .

7. Song J, Su H, Zhou YY, Guo LL. Prognostic value of survivin expression in breast cancer patients: a metaanalysis. Tumour Biol, 2013,34(4): 2053-2062.

8. Hinnis $A R$, Luckett $J C$, Walker $R$ A. Survivin is an independent predictor of short-term survival in poor prognostic breast cancer patients. Br J Cancer 2007, 96(4): 639-645.

9. Sakasai $R$, Teraoka $H$, Takagi $M$, Tibbetts $R S$. Transcription-dependent activation of ataxia telangiectasia mutated prevents DNA-dependent protein kinase-mediated cell death in response to topoisomerase I poison. J Biol Chem 2010; 285(20): 15201-15208.

10. Venkatakrishnan $C D$, Dunsmore $K$, Wong $H$, Roy $S$, Sen CK, Wani A, Zweier JL, llangovan G. HSP27 regulates

Trop J Pharm Res, February 2019; 18(2): 240 
p53 transcriptional activity in doxorubicin-treated fibroblasts and cardiac H9c2 cells: p21 upregulation and G2/M phase cell cycle arrest. Am J Physiol Heart Circ Physiol 2008; 294(4): H1736-1744.

11. Anan K, Tanaka M, Yoshinaga Y, Maeda S, Yamaguchi Y, Hayashi M, Tanaka M, Kamata Y, Mashino K, Yamamoto $Y$, et al. Effect of weekly paclitaxel followed by 5-fluorouracil, epirubicin, and cyclophosphamide as neoadjuvant treatment for patients with triple-negative and luminal-type breast cancer - a multicenter study. Gan To Kagaku Ryoho 2015; 42(1): 45-50.

12. Hoffman WH, Biade S, Zilfou JT, Chen J, Murphy M. Transcriptional repression of the anti-apoptotic survivin gene by wild type p53. J Biol Chem 2002, 277(5): 32473257.

13. O'Reilly M A. Redox activation of p21Cip1/WAF1/Sdi1: a multifunctional regulator of cell survival and death. Antioxid Redox Signal 2005, 7(1-2): 108-718

14. Xu $Q$, Liu $M, X u N$. Variation in Sp1 binding sites correlates with expression of survivin in breast cancer. Mol Med Rep 2014; 10(3): 1395-1399.

15. Jiang $Y$, Saavedra HI, Holloway MP, Leone G, Altura RA. Aberrant regulation of survivin by the RB/E2F family of proteins. J Biol Chem 2004; 279: 40511-40520.
16. Kim KH, Yoon G, Cho JJ. Licochalcone $A$ induces apoptosis in malignant pleural mesothelioma through downregulation of Sp1 and subsequent activation of mitochondria-related apoptotic pathway. Int $\mathrm{J}$ Oncol 2015; 46(3): 1385-1392.

17. Nawrocki ST, Carew JS, Douglas L, Cleveland JL, Humphreys $R$, Houghton JA. Histone deacetylase inhibitors enhance lexatumumab-induced apoptosis via a p21Cip1-dependent decrease in survivin levels. Cancer Res 2007; 67: 6987-6994.

18. Balasubramanyam $K$, Varier RA, Altaf $M$, Swaminathan $V$, Siddappa NB, Ranga U, Kundu TK. Curcumin, a novel p300/CREB-binding protein-specific inhibitor of acetyltransferase, represses the acetylation of histone/nonhistone proteins and histone acetyltransferase-dependent chromatin transcription. J Biol Chem 2004; 279(49): 51163-51171.

19. Ma H, Nguyen C, Lee KS, Kahn M. Differential roles for the coactivators CBP and p300 on TCF/-cateninmediated survivin gene expression. Oncogene 2005; 24: 3619-3631.

20. Zhu N, Gu L, Findley HW, Chen C, Dong JT, Yang L, Zhou M. KLF5 Interacts with p53 in regulating survivin expression in acute lymphoblastic leukemia. J Biol Chem 2006; 281(21): 14711-14718. 